\title{
Developmental Changes in NMDA Receptor Glycine Affinity and Ifenprodil Sensitivity Reveal Three Distinct Populations of NMDA Receptors in Individual Rat Cortical Neurons
}

\author{
James N. C. Kew, J. Grayson Richards, Vincent Mutel, and John A. Kemp \\ Pharma Division, Preclinical CNS Research, F. Hoffmann-La Roche Ltd., CH-4070 Basel, Switzerland
}

Previous work with recombinant receptors has shown that the identity of the NMDA NR2 subunit influences receptor affinity for both glutamate and glycine. We have investigated the developmental change in NMDA receptor affinity for both glutamate and glycine in acutely dissociated parietal cortex neurons of the rat, together with the expression during ontogeny of NR2A and NR2B mRNA and protein. Whereas there is little change in NMDA receptor glutamate affinity with age, a population of NMDA receptors emerges in 14- and 28-d-old animals with a markedly reduced affinity for glycine $\left(m K_{D}=\sim 800 \mathrm{~nm}\right)$ and a reduced sensitivity to the NR2B subunit-selective NMDA antagonist ifenprodil. These changes are paralleled by a developmental increase in the expression of NR2A. Thus, in mature animals a population of NMDA receptors appears with a lower affinity for glycine that might not be saturated under normal physiological conditions. Ifenprodil $(10 \mu \mathrm{M})$ inhibits virtually all of the NMDA receptor-evoked current in very young neurons that contain a single population of receptors exhibiting a high affinity for glycine $\left(m K_{\mathrm{D}}=\sim 20 \mathrm{~nm}\right)$. In older neurons, which contain NMDA receptors with both high and low affinities for glycine, ifenprodil $(10 \mu \mathrm{M})$ inhibits both the high-affinity population and a significant proportion of the low-affinity component, thus revealing three pharmacologically distinct populations of NMDA receptors in single neurons. Moreover, these observations suggest that ifenprodil might bind with high affinity to NMDA receptors containing both NR2A and NR2B subunits as well as those containing only NR2B.

Key words: NMDA receptor; glycine; ifenprodil; NMDA receptor subtype; glutamate receptor; NR2A; NR2B
The NMDA receptor is unique among ligand-gated ion channels in its requirement for two co-agonists, acting at the glutamate and glycine recognition sites, for receptor activation (Johnson and Ascher, 1987; Kleckner and Dingledine, 1988). The physiological role of the glycine site in the regulation of $\mathrm{NMDA}$ receptor activity remains unclear. Whereas both co-agonists are required for receptor activation, it is glutamate that appears to play the neurotransmitter role, being released from presynaptic terminals in an activity-dependent manner, whereas glycine is apparently present at a more constant level, indicating a more modulatory function (for review, see Kemp and Leeson, 1993). Measurements of glycine concentration in the extracellular and cerebrospinal fluids suggest that it is present at low micromolar levels (Westergren et al., 1994), concentrations that have been considered saturating for NMDA receptors.

A number of groups have investigated the effects of application of exogenous glycine on NMDA-mediated responses both in vivo and in brain slices in vitro. Several studies failed to observe any potentiation of NMDA responses (Fletcher and Lodge, 1988; Kemp et al., 1988; Llano et al., 1988; Obrenovitch et al., 1997), suggesting that the levels of glycine were indeed saturating. However, others have observed positive modulation of NMDAevoked responses, indicating that the glycine site may not be fully saturated (Danysz et al., 1989; Thomson et al., 1989; Wood et al.,

\footnotetext{
Received Oct. 23, 1997; revised Dec. 11, 1997; accepted Dec. 23, 1997.

We thank Jürg Messer, Zaiga Bleuel, and Danièle Buchy for expert technical assistance.

Correspondence should be addressed to John A. Kemp, Pharma Division, Preclinical CNS Research, F. Hoffmann-La Roche Ltd., Building 69/412, CH-4070 Basel, Switzerland.

Copyright (C) 1998 Society for Neuroscience $\quad 0270-6474 / 98 / 181935-09 \$ 05.00 / 0$
}

1989; Singh et al., 1990; Wilcox et al., 1996). Notably, the glycine transporter GLYT-1 is expressed in forebrain regions where no inhibitory glycinergic neurons have been detected (Smith et al., 1992, Borowsky et al., 1993, Zafra et al., 1995), indicating a possible role in the regulation of NMDA receptor-mediated neurotransmission.

Receptor cloning studies have identified several NMDA receptor subunits, NMDA receptor 1 (NMDAR1), of which eight splice variants have been described, and four NR2 subunits, A-D, which are believed to assemble in various combinations to generate heteromeric complexes predicted to contain four (Laube et al., 1997) or five subunits (for review, see McBain and Mayer, 1994). NMDAR1 is believed to be an obligate component of functional receptors, because NR2 subunits are unable to form functional NMDA receptors when expressed alone. However, co-expression of NMDAR1 with one or more of the NR2 subunits readily generates receptors with distinct functional and pharmacological properties that appear to best resemble native receptors (Kutsuwada et al., 1992; Monyer et al., 1992). The NR2 subunits are expressed differentially in a spatiotemporal manner (for review, see McBain and Mayer, 1994), which together with the differential expression of the NMDAR1 isoforms suggests the existence of a variety of native NMDA receptors. In the forebrain, the predominant NR2 subunits are NR2A and NR2B, and thus, the most abundant heteromeric receptor combinations are likely to be NMDAR1-NR2A, NMDAR1-NR2B, and, possibly, three-subunit-containing NMDAR1-NR2A-NR2B receptors (Sheng et al., 1994, Luo et al., 1997). Notably, recombinant NMDAR1-NR2A receptors exhibit $\sim 10$-fold lower affinity for glycine and $\sim 400$-fold lower affinity for the noncompetitive antagonist ifenprodil, relative to NMDAR1-NR2B receptors (Kut- 
suwada et al., 1992; Williams, 1993; Priestley et al., 1995); however, the pharmacological properties of NMDAR1-NR2ANR2B receptors are unknown.

Using whole-cell patch-clamp recordings, we have examined NMDA receptor affinity for both glutamate and glycine in acutely dissociated rat cortical neurones from 2- to 3-, 14- to 15-, and 27 to 29-d-old animals. We have also examined the expression of NR2A and NR2B mRNA and protein at these time points by in situ hybridization histochemistry and Western blot analysis and investigated the sensitivity of the receptors to the NR2B subunitselective NMDA receptor antagonist ifenprodil.

\section{MATERIALS AND METHODS}

\section{Acute cortical neuronal dissociation}

Brain slices $(450 \mu \mathrm{m})$ from 2- to $3-, 14-$ to $15-$, or 27 - to 29 -d-old rats (Roro specific pathogen-free (spf) 120) were cut with a vibratome in an ice-cold solution that contained (in $\mathrm{mM}$ ): $\mathrm{NaCl} 125, \mathrm{KCl} 2.5, \mathrm{CaCl}_{2} 2$, $\mathrm{MgCl}_{2} 1, \mathrm{NaH}_{2} \mathrm{PO}_{4} 1.25, \mathrm{NaHCO}_{3} 26$, and D-glucose 25, $\mathrm{pH}$ adjusted to 7.4 with oxycarbon $\left(95 \% \quad \mathrm{O}_{2}\right.$ and $\left.5 \% \quad \mathrm{CO}_{2}\right)$, and were subsequently incubated at $20^{\circ} \mathrm{C}$ in the same solution. All reagents were obtained from Sigma (St. Louis, MO) unless stated otherwise. When neurons were needed for electrophysiological experiments, the parietal cortex was dissected out of each slice and treated for $10 \mathrm{~min}$ at $37^{\circ} \mathrm{C}$ with a solution containing (in mM): $\mathrm{Na}_{2} \mathrm{SO}_{4} 82, \mathrm{~K}_{2} \mathrm{SO}_{4} 30, \mathrm{MgCl}_{2} 3$, and HEPES 2, and $1 \mathrm{mg} / \mathrm{ml}$ papain, $\mathrm{pH}$ adjusted to 7.4 with $\mathrm{NaOH}$. The cortex was then dissected into small $\left(1-2 \mathrm{~mm}^{2}\right)$ pieces and washed in an identical solution without papain, and neurons were isolated by gentle trituration with a Pasteur pipette with a narrow flame-polished tip in an identical solution. Neurons were then plated on poly-L-ornithine $\left(1 \mathrm{mg} / \mathrm{ml}\right.$ in $\left.\mathrm{H}_{2} 0\right)$-coated glass coverslips.

\section{Whole-cell voltage-clamp recordings}

Whole-cell voltage-clamp recordings were performed as described previously (Kew et al., 1996). Neurons were continuously perfused with a simple salt solution (in mM: $\mathrm{NaCl} 149, \mathrm{KCl} 3.25, \mathrm{CaCl}_{2} 2, \mathrm{MgCl}_{2} 2$, HEPES 10, and D-glucose 11, pH adjusted to 7.35 with $\mathrm{NaOH}$ and osmolarity adjusted to $350 \mathrm{mOsm}$ using sucrose). Patch pipettes were pulled from thin-walled borosilicate glass (GC150TF; Clark Electromedical Instruments, Pangbourne, UK) using a DMZ universal electrode puller. Pipettes had resistances of $\sim 2-4 \mathrm{M} \Omega$ when filled with patch pipette solution (in mM: $\mathrm{CsF} 120, \mathrm{CsCl} 10$, EGTA $11, \mathrm{CaCl}_{2} 0.5$, and HEPES $10, \mathrm{pH}$ adjusted to 7.25 with $\mathrm{CsOH}$ and osmolarity adjusted to $330 \mathrm{mOsm}$ with sucrose). Whole-cell current recordings were made from neurons at a holding potential of $-60 \mathrm{mV}$ using an Axopatch 200A amplifier (Axon Instruments, Foster City, CA). Pipette seal resistances were typically $>10 \mathrm{G} \Omega$, and pipette capacitance transients were minimized both before and after membrane breakthrough. No series resistance compensation was applied. Drugs were diluted from concentrated stock solutions into a modified version of the salt solution used to perfuse the culture that lacked $\mathrm{MgCl}_{2}$. Drugs were applied to cells by fast perfusion from a double- or triple-barreled capillary assembly composed of large-tipped $(\sim 350 \mu \mathrm{m})$ capillaries with an internal diameter of 320 $\mu \mathrm{m}$. Solution equilibration times were determined by stepping from a solution of kainate $(100 \mu \mathrm{M})$ in $10 \mathrm{~mm} \mathrm{NaCl}$ to one containing $149 \mathrm{~mm}$ $\mathrm{NaCl}$. The mean $\pm \mathrm{SE}$ time constant of the exponential increase in membrane current after such a step was $29.2 \pm 1.5 \mathrm{msec}$ (Kew et al., 1996). Ifenprodil was obtained from Synthelabo Recherche (Bagneux, France).

\section{Equilibrium concentration-response curves}

Best fit lines were computed for equilibrium concentration-response data using a two-equivalent binding site model for monophasic fits:

$$
I=I_{\max } /\left(1+\left(m K_{\mathrm{D}} /[A]\right)\right)^{2}
$$

where $m K_{\mathrm{D}}$ is the microscopic dissociation constant, and $[A]$ is the agonist concentration. Data were fitted with a $2 \times 2$ equivalent binding site model for biphasic fits:

$$
I=I_{\max (\mathrm{H})} /\left(1+\left(m K_{\mathrm{D}(\mathrm{H})} /[A]\right)\right)^{2}+I_{\max (\mathrm{L})} /\left(1+\left(m K_{\mathrm{D}(\mathrm{L})} /[A]\right)\right)^{2}
$$

where $I_{\max (\mathrm{H})}$ and $I_{\max (\mathrm{L})}$ are the current amplitudes of the high- and low-affinity components of the concentration-response curve, and $m K_{\mathrm{D}(\mathrm{H})}$ and $m K_{\mathrm{D}(\mathrm{L})}$ are the microscopic dissociation constants for the high- and low-affinity components of the curve.

A baseline contamination of glycine was present in all solutions, illustrated by a consistent, small response evoked by the application of NMDA in the absence of added glycine. To correct for this glycine contamination, glycine concentration-response data for each neuron were initially fitted with a modified version of either the two-equivalent binding site model:

$$
I=I_{\max } /\left(1+\left(m K_{\mathrm{D}} /[A+g]\right)\right)^{2}
$$

or the $2 \times 2$ equivalent binding site model:

$$
I=I_{\text {maxH }} /\left(1+\left(m K_{\mathrm{D}(\mathrm{H})} /[A+g]\right)\right)^{2}+I_{\text {maxl }} /\left(1+\left(m K_{\mathrm{D}(\mathrm{L})} /[A]\right)\right)^{2}
$$

incorporating a variable, $g$, representing the basal contaminating glycine concentration. For the $2 \times 2$ equivalent binding site model, the variable $g$ is only included in the term defining the high-affinity interaction, in which the effects of the contaminating glycine are most pronounced.

The derived contaminating glycine concentration was then added to each glycine concentration used in the concentration-response curve to give the true glycine concentrations. The concentration-response curve was then replotted using the true glycine concentrations and fitted with the appropriate equation excluding the term for the contaminating glycine ( $g$ ) (i.e., Eq. 1 or 2). Plotting the current evoked by NMDA in the absence of added glycine against the predicted contaminating glycine concentration provided a control for the accuracy of this correction procedure. The mean calculated contaminating glycine concentration was $20 \pm 2 \mathrm{nM}($ mean $\pm \mathrm{SE} ; n=24)$. Affinity estimates are quoted either as the apparent microscopic dissociation constant $\left(m K_{\mathrm{D}}\right)$ or as the corresponding negative logarithm $\left(\mathrm{p} m K_{\mathrm{D}}\right)$ to enable statistical analysis of the data.

\section{Inhibition curves}

Inhibition curves were fitted according to a modified version of the Hill equation with baseline, which describes a two-binding site isotherm:

$$
\begin{array}{r}
I=I_{\max (\mathrm{H})} /\left(1+\left([A] / \mathrm{IC}_{50(\mathrm{H})}\right)^{s(\mathrm{H})}\right)+I_{\max (\mathrm{L})} /\left(1+\left([A] / \mathrm{IC}_{50(\mathrm{~L})}\right)^{s(\mathrm{~L})}\right)+(100 \\
\left.-I_{\max (\mathrm{H})}-I_{\max (\mathrm{L})}\right)
\end{array}
$$

where $I_{\max (\mathrm{H})}$ and $I_{\max (\mathrm{L})}$ are the relative percentages of the high- and low-affinity components of the antagonism, $[A]$ is the antagonist concentration, $\mathrm{IC}_{50(\mathrm{H})}$ and $\mathrm{IC}_{50(\mathrm{~L})}$ are the concentrations of antagonist required to reduce the agonist response to $50 \%$ of the control value for each component of the curve, and $s(\mathrm{H})$ and $s(\mathrm{~L})$ are the slopes of the fitted lines for the high- and low-affinity components, respectively.

\section{Exponential curve fitting}

Neuronal currents were filtered (cutoff frequency, $5 \mathrm{kHz}$ ), digitized using a Digidata 1200 (Axon Instruments), and captured on-line to the hard disk of a Gateway 2000 P4D-66 computer using Axoscope software (Axon Instruments). Jumps into and out of $1 \mathrm{~mm}$ 7-chlorokynurenic acid (Research Biochemicals, Natick, MA) were performed three times for each cell and averaged using Axoscope software. All curves were fitted using GraphPad Prism software (GraphPad Software, San Diego, CA). The recovery of the steady-state current after the rapid removal of 7-chlorokynurenic acid was best fitted by a curve-fitting model assuming that channel gating requires the binding of two agonist molecules to two equivalent sites according to the equation:

$$
I=B_{0}-A(1-\exp (-t / \tau))^{2}
$$

where $B_{0}$ is the current baseline before the start, $A$ is the current response amplitude, $t$ is time, and $\tau$ is the time constant for agonist occupation of each independent site.

\section{In situ hybridization analysis}

Tissue preparation. Rat brains were rapidly dissected from halothaneanesthetized 3-, 14-, or 28-d-old Roro spf 120 rats and immediately frozen in dry ice. Parasagittal cryostat sections $(\sim 12 \mu \mathrm{m}$ thick $)$ of brain were mounted on Superfrost Plus slides (Menzel-Gläser) and fixed in $4 \%$ paraformaldehyde (in PBS, pH 7.4) for $20 \mathrm{~min}$, followed by three $5 \mathrm{~min}$ washes in PBS.

Probe labeling. Oligodeoxyribonucleotide probes, prepared on a DNA synthesizer (Genosys Biotechnologies) complementary to the rat NR2A 
and NR2B subunit cDNAs (bp $-69 \rightarrow-10$ and $-86 \rightarrow-27$, respectively (Monyer et al., 1992)), were used. The oligomers were labeled at the $3^{\prime}$ end with terminal deoxynucleotidyl-transferase (Life Technologies, Basel, Switzerland) and $\left[{ }^{35} \mathrm{~S}\right] \mathrm{dATP}$ (New England Nuclear, Boston, $\mathrm{MA})$. The reaction mixture $(50 \mu \mathrm{l}$ total $)$ contained $5.5 \mu \mathrm{l}$ of $\left[{ }^{35} \mathrm{~S}\right] \mathrm{dATP}$ $10 \mu \mathrm{l}$ of tailing buffer (Life Technologies; in mM: potassium cacodylate $500, \mathrm{pH} 7.2, \mathrm{CoCl}_{2} 10$, and dithiothreitol 1), $1 \mu \mathrm{l}$ of oligomer $(100 \mathrm{ng} / \mathrm{ml})$, $1 \mu \mathrm{l}$ of bovine serum albumin ( $2 \mathrm{mg} / \mathrm{ml}$, RNase- and DNase-free ), $6.5 \mu \mathrm{l}$ of terminal deoxynucleotidyl transferase (Life Technologies; $15 \mathrm{U} / \mu \mathrm{l}$ ) and $26 \mu \mathrm{l}$ of $\mathrm{H}_{2} \mathrm{O}$. The mixture was transferred to $37^{\circ} \mathrm{C}$ for $5 \mathrm{~min}$, and then the reaction was stopped by adding $5 \mu \mathrm{l}$ of EDTA $(0.5 \mathrm{M})$ and transferring the mixture to $75^{\circ} \mathrm{C}$ for $10 \mathrm{~min}$. The labeled probes were separated from unincorporated nucleotides with a Biogel P30 spun column (Bio-Rad, Glattbrugg, Switzerland; $2 \times 4 \mathrm{~min}$ at $1600 \times \mathrm{g}$ ).

\section{In situ hybridization histochemistry}

Sections were hybridized with $50 \mu \mathrm{l}$ of a solution with the following constituents: $4 \times$ SSC, $20 \%$ dextran sulfate, $0.25 \mathrm{mg} / \mathrm{ml}$ tRNA (Boehringer Mannheim, Mannheim, Germany), $0.25 \mathrm{mg} / \mathrm{ml}$ salmon testes DNA, 50\% deionized formamide (Bethesda Research Laboratories, Bethesda, MD), $0.1 \mathrm{~m}$ dithiothreitol (Fluka, Buchs, Switzerland), $0.5 \times$ Denhard's solution, and ${ }^{35}$ S-labeled probe $\left(3 \times 10^{5} \mathrm{cpm}\right)$. Sections covered with strips of Fujifilm were incubated in a humid chamber at $43^{\circ} \mathrm{C}$ for $20-24 \mathrm{hr}$. After removal of the strips, the sections were washed twice in a solution containing $1 \times$ SSC and $10 \mathrm{~mm}$ dithiothreitol for 15 min each at $55^{\circ} \mathrm{C}$, then twice in $0.5 \times \mathrm{SSC}$ and $10 \mathrm{~mm}$ dithiothreitol for 15 min each at $55^{\circ} \mathrm{C}$, and then finally once in $0.5 \times$ SSC and $10 \mathrm{~mm}$ dithiothreitol for $15 \mathrm{~min}$ at room temperature. After a dip in doubledistilled water, sections were dehydrated in ethanol and exposed for up to 4 weeks at $4^{\circ} \mathrm{C}$ to sheet film (Hyperfilm, $\beta$-Max; Amersham, Zürich, Switzerland) to reveal the regional localization of the mRNA. The film was developed in Kodak PL12 then transferred to Kodak Rapid Fix. The films were used as negatives to produce reverse images, i.e., white areas revealing high levels of hybridization signal on a black background. Densitometric analysis of hybridization signal in the parietal cortex (four readings per cortex from four sections per parameter) was performed using a computer-assisted image analyzer (MCID-M2; Imaging Research Inc., St. Catherine's, Ontario, Canada).

\section{Western blot analysis}

Membrane preparation. Parietal cortices were dissected from 3-, 14-, or 28-d-old Roro spf 120 rats and were homogenized with a Polytron $\left(14,000 \mathrm{rpm}\right.$; Kinematica AG, Littau, Switzerland) at $4^{\circ} \mathrm{C}$ in 100 volumes (w/v) of Tris- $\mathrm{HCl}, 10 \mathrm{~mm}$; and sucrose, $0.32 \mathrm{M}, \mathrm{pH}$ 7.4. The homogenate was then centrifuged at $700 \times g$ for $10 \mathrm{~min}$ at $4^{\circ} \mathrm{C}$. The resulting pellet was rehomogenized, as above, and the homogenate was spun down. The supernatants from the two centrifugations were combined and centrifuged at $37,000 \times g$ for $40 \mathrm{~min}$ at $4^{\circ} \mathrm{C}$. The pellet was then resuspended in the same volume of Tris- $\mathrm{HCl}, 10 \mathrm{~mm}, \mathrm{pH} 7.4$, and the preparation was frozen at $-80^{\circ} \mathrm{C}$.

Membrane solubilization. After thawing, the membranes were centrifuged at $20,000 \times g$ for $10 \mathrm{~min}$ at $4^{\circ} \mathrm{C}$, and the pellets were solubilized in a buffer containing HEPES, $20 \mathrm{~mm} ; \mathrm{NaCl}, 150 \mathrm{mM} ; \mathrm{MgCl}_{2}, 1.5 \mathrm{~mm}$; EGTA, 1 mM; glycerol, 10\%; Triton X-100, 1\%; SDS, 0.1\%; leupeptin, 10 $\mu \mathrm{g} / \mathrm{ml}$; PMSF, $1 \mathrm{~mm}$; and aprotinin, $10 \mu \mathrm{g} / \mathrm{ml}, \mathrm{pH}$ 7.5. The lysates were sonicated and incubated for $1 \mathrm{hr}$ at $4^{\circ} \mathrm{C}$. After centrifugation at $26,000 \times$ $g$ for $20 \mathrm{~min}$ at $4^{\circ} \mathrm{C}$, the protein concentration was determined in an aliquot of each preparation using the BCA method (Pierce, Socochim, Lausanne, Switzerland) with bovine serum albumin as standard.

Western blot. The individual lysates were diluted in a Laemmli buffer (Tris-HCl, $250 \mathrm{~mm}$; SDS, 4\%; glycerol, 20\%; bromophenol blue, 0.06 $\mathrm{mg} / \mathrm{ml}$; and dithiothreitol, $0.1 \mathrm{M}, \mathrm{pH} 6.8$ ) to the same final protein concentration and heated for $5 \mathrm{~min}$ at $95^{\circ} \mathrm{C}$. Ten micrograms of membrane protein were separated by gel electrophoresis using a 7.5\% acrylamide gel and blotted overnight onto a nitrocellulose filter $(0.2 \mu \mathrm{m}$, Bio-Rad). Prestained broad-range SDS-PAGE standards (Bio-Rad) were run on each gel. The filters were blocked in PBS containing 5\% skimmed milk powder and incubated with a solution containing $1 \mathrm{mg} / \mathrm{ml}$ of an antibody to NR2A (AB 1555P; Chemicon, Luzern, Switzerland) or 1 $\mathrm{mg} / \mathrm{ml}$ of an antibody to NR2B (AB 1557P, Chemicon). After washing, the filter was incubated in horseradish peroxidase-conjugated goat antirabbit Ig (1:3000), washed, and developed to reveal bound antibody using an ECL kit (Amersham). A standard curve, made with a gradient of protein from cortices of 28-d-old rat brains, was run in parallel to calibrate the samples. Films were scanned with a Hewlett Packard Scan-
Jet 4C scanner and subsequently analyzed by measuring optical densities of the immunostained bands on the film using one-dimensional image analysis software (Kodak Digital Science). Densitometric values for the experimental rat brain samples were always within the range of values encompassed by the standard curve.

\section{RESULTS}

\section{Developmental change in NMDA receptor glycine affinity}

Glycine and glutamate concentration-response curves were performed using whole-cell voltage-clamp recordings from acutely dissociated rat cortical neurons prepared from 2- to 3-, 14- to 15-, and 27- to 29-d-old rats. Glycine concentration-response curves were constructed by jumping rapidly from a control solution to one containing $100 \mu \mathrm{M}$ NMDA in the presence of increasing concentrations of glycine in both the control and NMDA solutions. Neurons from 2- to 3-d-old animals consistently exhibited monophasic glycine concentration-response curves (Fig. 1A,B) with a mean $\mathrm{p} m K_{\mathrm{D}}$ of $7.75 \pm 0.06$ (mean $\pm \mathrm{SE} ; n=8$ neurons) and a maximum response at $\sim 1 \mu \mathrm{M}$ glycine. A plot of data from all neurons normalized to their respective individual $1 \mu \mathrm{M}$ glycine response fitted with the two-equivalent binding site model (Eq. 1) yielded an $m K_{\mathrm{D}}$ of $18 \mathrm{~nm}$ (Fig. $1 C$ ).

Neurons from 27- to 29-d-old rats generated biphasic glycine concentration-response curves (Fig. $2 A-C$ ). The mean $\mathrm{p} m K_{\mathrm{D}}$ values of the high- and low-affinity components were $7.40 \pm 0.07$ and $6.08 \pm 0.08$, respectively $(n=8$ cells), with the mean amplitudes of the high- and low-affinity components of $53 \pm 5$ and $47 \pm 5 \%$, respectively. The proportion of the high-affinity component in individual neurons ranged from a minimum of 30 to a maximum of $75 \%$. Data from all neurons were normalized to their respective individual $30 \mu \mathrm{M}$ glycine responses, plotted together, and fitted with the $2 \times 2$ equivalent binding site model (Eq. 2), yielding high- and low-affinity $m K_{\mathrm{D}}$ values of 41 and 774 nM, respectively (Fig. 2C). Notably, the maximum response was achieved with $\sim 30 \mu \mathrm{M}$ glycine, and $1 \mu \mathrm{M}$ glycine elicited an $\sim 60 \%$ maximal response (Fig. $2 A-C$ ). Thus, in 27 - to 29 -d-old animals a population of NMDA receptors appears with a lower affinity for glycine (Fig. 2D).

Fourteen- to 15-d-old animals yielded a mixed population of neurons, most of which exhibited monophasic glycine concentration-response curves, with a minority exhibiting biphasic curves. Of nine neurons tested, seven exhibited monophasic curves with a maximum response at $\sim 1 \mu \mathrm{M}$ glycine and a mean $\mathrm{p} m K_{\mathrm{D}}$ of $7.65 \pm 0.06$. Two neurons exhibited biphasic curves with a maximum response at $\sim 30 \mu \mathrm{M}$ glycine and with $m K_{\mathrm{D}}$ values of 20 and $44 \mathrm{~nm}$ for the high-affinity component and 1100 and $860 \mathrm{~nm}$ for the low-affinity component. Amplitudes of the high-affinity component were 46 and $84 \%$ and for the low-affinity component were 54 and $16 \%$, respectively.

Glutamate concentration-response curves were constructed by jumping rapidly from a control solution to one containing increasing concentrations of glutamate in the continuous presence of 30 $\mu \mathrm{M}$ glycine and $10 \mu \mathrm{M}$ NBQX (to prevent activation of AMPA and kainate receptors) in both the control and glutamatecontaining solutions. Glutamate concentration-response curves from all three age groups were monophasic. Fits of the mean data with the two-equivalent binding site model yielded $m K_{\mathrm{D}}$ values of $1.4,2.3$, and $2.4 \mu \mathrm{M}$ for $2-$ to $3-, 14-$ to $15-$, and $27-$ to $29-\mathrm{d}-\mathrm{old}$ animals, respectively, and maximum responses for all three age groups at $\sim 300 \mu \mathrm{M}$ glutamate (Fig. 3).

On completion of concentration-response curves with both glutamate and glycine, we assessed the inhibition of currents 
A

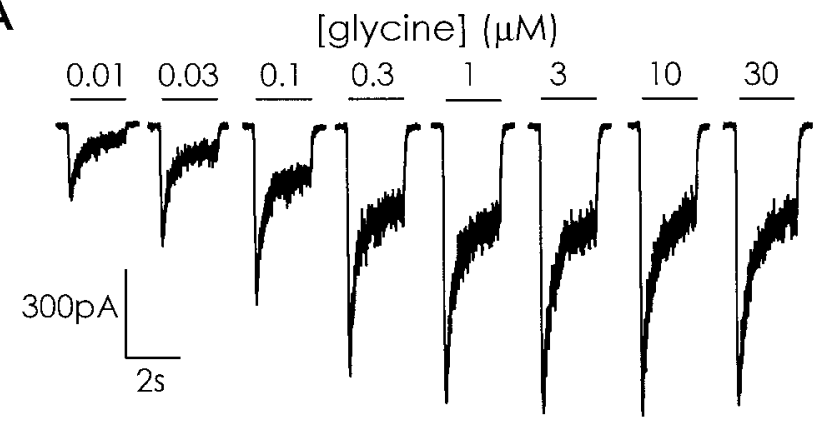

B

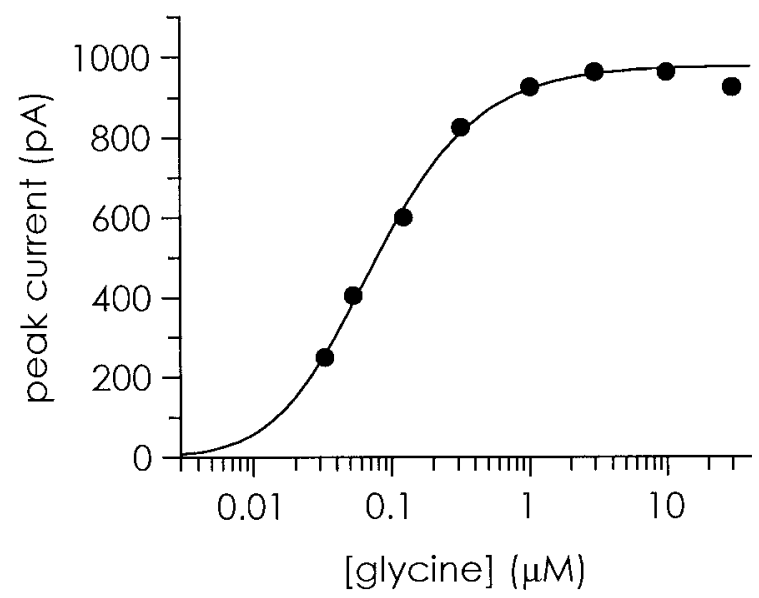

C

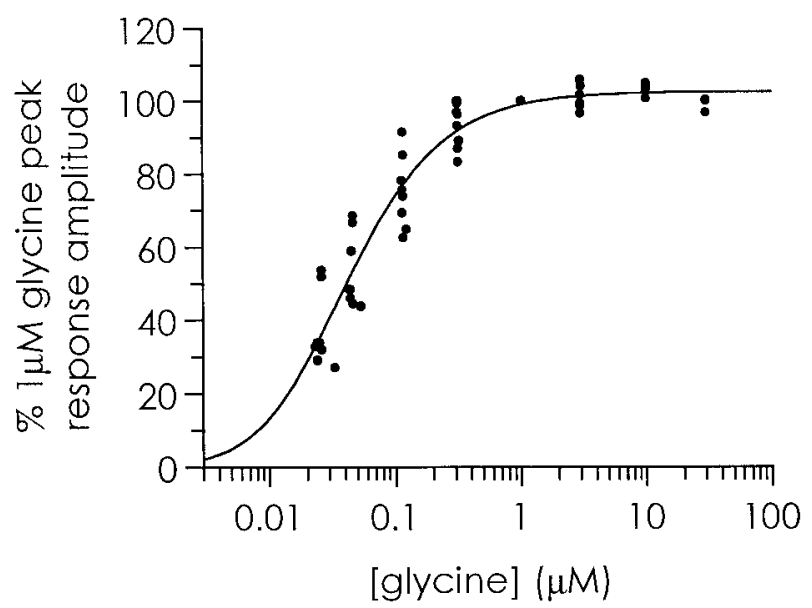

Figure 1. Glycine concentration-response curves from 2- to 3-d-old cortical neurons. $A$, Representative glycine concentration-response data from a typical neuron. Inward currents were elicited in response to $2 \mathrm{sec}$ fast applications of $100 \mu \mathrm{M}$ NMDA at $29 \mathrm{sec}$ intervals (intervening sections of the trace have been omitted for clarity) in the presence of increasing concentrations of glycine. Applied glycine concentrations are shown. The baseline glycine contamination was calculated as $23 \mathrm{~nm}$. Therefore, the true glycine concentration was calculated as the applied glycine concentration plus $23 \mathrm{nM}$. $B$, Plot of the glycine concentrationpeak current response data from $A$. Shown is a monophasic curve fitted with the two-equivalent binding site model that yielded an $m K_{\mathrm{D}}$ of $31 \mathrm{~nm}$. $C$, Plot of the glycine concentration-response data from eight neurons. Data from each neuron have been normalized to their respective individual $1 \mu \mathrm{M}$ glycine peak response. Shown is a curve fitted with the twoequivalent binding site model that yielded an $m K_{\mathrm{D}}$ of $18 \mathrm{~nm}$. evoked by a maximal concentration of the appropriate agonist, together with the appropriate co-agonist, by $10 \mu \mathrm{M}$ ifenprodil. Ifenprodil $(10 \mu \mathrm{M})$ was applied continuously, and agonist applications were made until stable steady-state current levels were attained. In neurons from 2- to 3-, 14- to 15-, and 27- to 29-d-old animals, $10 \mu \mathrm{M}$ ifenprodil inhibited $90 \pm 2,68 \pm 3$, and $65 \pm 4 \%$ of the steady-state current, respectively ( $n=7,15$, and 9, respectively). Thus, ifenprodil sensitivity is reduced in an agedependent manner. Notably, in 28-d-old animals the mean amplitude of the high-affinity component of the glycine concentration-response curves was $53 \pm 5 \%$, whereas ifenprodil inhibited significantly more of the steady-state current $(65 \pm 4 \%$; one-tailed $t$-test, $p<0.05$ ), suggesting that ifenprodil might inhibit a proportion of NMDA receptors exhibiting low affinity for glycine together with those exhibiting high affinity. We obtained ifenprodil inhibition curves against $100 \mu \mathrm{M}$ NMDA-evoked steady-state currents in the continuous presence of $30 \mu \mathrm{M}$ glycine using 27- to 29-d-old neurons (Fig. 4). As demonstrated previously with cultured neurons (Priestley et al., 1994), inhibition curves to ifenprodil were biphasic, with $\mathrm{IC}_{50}$ values of 0.21 and 58 $\mu \mathrm{M}$ for the high- and low-affinity components, respectively. The relative amplitudes of the high- and low-affinity components were 70 and $30 \%$, respectively. Importantly, $10 \mu \mathrm{M}$ ifenprodil inhibited the high-affinity component completely but left the low-affinity component almost unaffected.

\section{Ifenprodil inhibits NMDA receptors with both high and low glycine affinities}

To further investigate the ability of $10 \mu \mathrm{M}$ ifenprodil to inhibit the high- and low-affinity glycine components of the NMDA current, a kinetic approach was used. The high- and low-affinity glycine components were revealed by rapid application of a high concentration of the glycine site antagonist 7-chlorokynurenic acid during a steady-state current evoked by $100 \mu \mathrm{M}$ glutamate in the continuous presence of $30 \mu \mathrm{M}$ glycine and $10 \mu \mathrm{M}$ NBQX. The decay of NMDA currents after rapid application of 7-chlorokynurenic acid in the presence of glycine has been demonstrated previously to reflect the rate of dissociation of glycine from the NMDA receptor, which is the rate-limiting step (Benveniste et al., 1990). The rate of dissociation of glycine varies significantly depending on the receptor affinity (Priestley and Kemp, 1993). In 2- to 3-d-old animals, the current decay after rapid application of $1 \mathrm{~mm} 7$-chlorokynurenic acid was well fitted by a single exponential with a mean on-rate time constant of $1327 \pm 57 \mathrm{msec}(n=10$ cells) (Fig. $5 \mathrm{~A})$. The recovery of the steady-state current after a rapid jump back into $100 \mu \mathrm{M}$ glutamate in the absence of 7-chlorokynurenic acid, which is likely to represent the rate of 7-chlorokynurenic acid unbinding, was, as would be predicted, best fitted by a two-equivalent binding site model (see Materials and Methods) that yielded a mean $\tau$ value of $77 \pm 4 \mathrm{msec}$. Notably, the speed of solution exchange using our perfusion system $(\tau=\sim 30 \mathrm{msec})$ renders the absolute accuracy of the fast measured time constants somewhat uncertain. Nevertheless, the measured 7-chlorokynurenic acid off rates were very similar to those reported previously by Benveniste et al. (1990). After recovery from the jumps into 7-chlorokynurenic acid, a rapid jump was made into $100 \mu \mathrm{M}$ glutamate and $10 \mu \mathrm{M}$ ifenprodil. Ifenprodil inhibited $93 \pm 1 \%$ of the steady-state current. In neurons from 27- to 29-d-old animals the current decay after rapid application of $1 \mathrm{~mm}$ 7-chlorokynurenic acid was well fitted by two exponentials, with mean on-rate time constants (and relative amplitudes $)$ of $94 \pm 10 \mathrm{msec}(64 \pm 2 \%)$ and $1644 \pm 223$ 

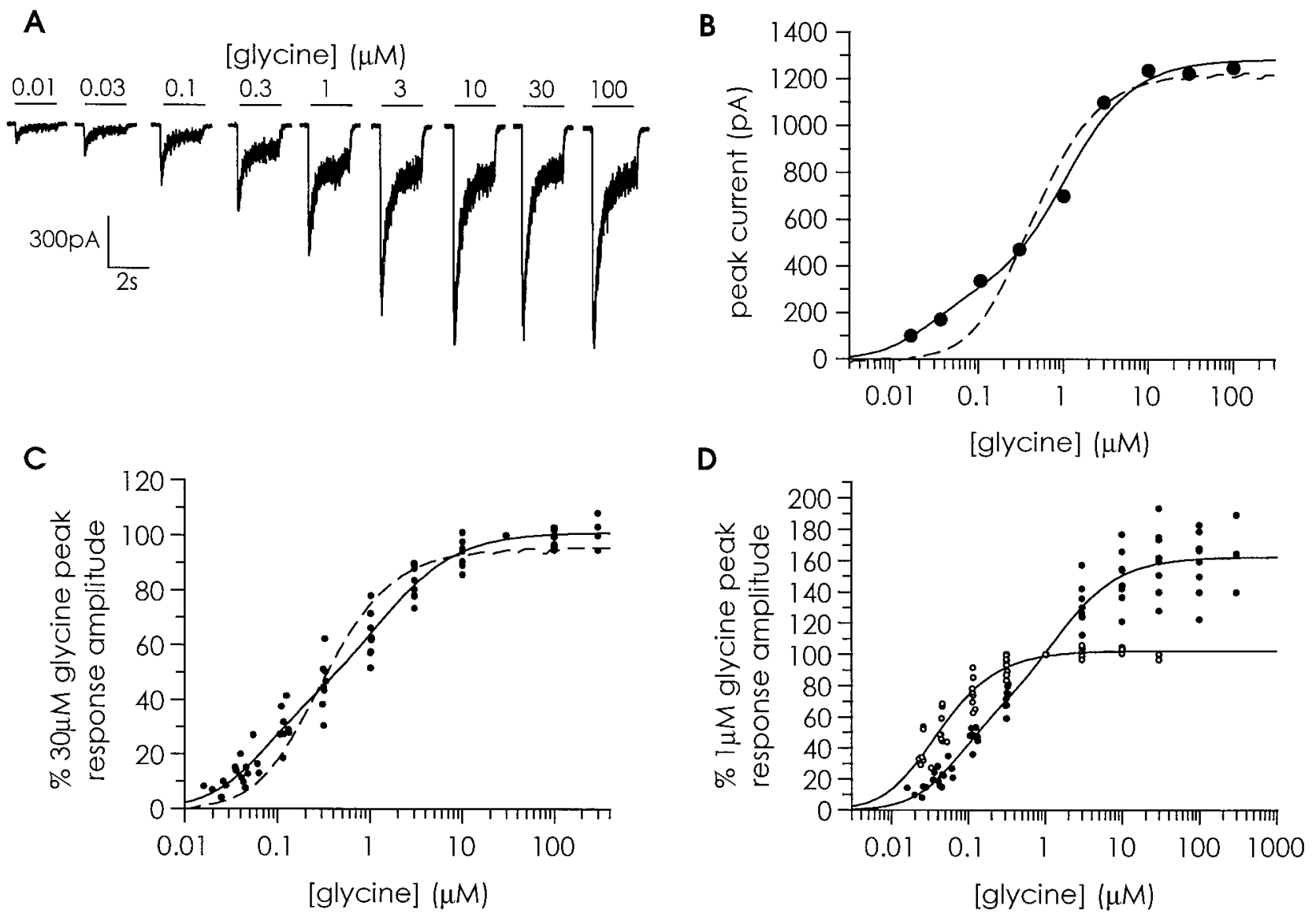

Figure 2. Glycine concentration-response curves from 27- to 29-d-old cortical neurons reveal a low-affinity glycine component. $A$, Representative glycine concentration-response data from a typical neuron. Inward currents were elicited in response to 2 sec fast applications of $100 \mu \mathrm{M}$ NMDA at 29 sec intervals (intervening sections of the trace have been omitted for clarity) in the presence of increasing concentrations of glycine. Applied glycine concentrations are shown. The baseline glycine contamination was calculated as $6 \mathrm{~nm}$. Therefore, the true glycine concentration was calculated as the applied glycine concentration plus $6 \mathrm{nM}$. $B$, Plot of the glycine concentration-peak current response data from $A$. Shown is a biphasic curve fitted with the $2 \times 2$ equivalent binding site model (solid line) that yielded $m K_{\mathrm{D}}$ values and relative amplitudes of $16 \mathrm{~nm}(30 \%)$ and $520 \mathrm{~nm}(70 \%)$ for the high- and low-affinity components, respectively. A monophasic curve fitted with the two-equivalent site model (broken line) is shown for comparative purposes. $C$, Plot of the glycine concentration-response data from eight neurons. Data from each neuron have been normalized to their respective individual $30 \mu \mathrm{M}$ glycine peak response. Shown is a biphasic curve fitted with the $2 \times 2$ equivalent binding site model (solid line) that yielded $m K_{\mathrm{D}}$ values and relative amplitudes of $41 \mathrm{nM}(52 \%)$ and $774 \mathrm{nM}(48 \%)$ for the high- and low-affinity components, respectively. The biphasic fit was significantly better than a monophasic fit using the two-equivalent biding site model (broken line) ( $p<0.001, F$ test). $D$, Comparison of glycine concentration-response data from 2 - to 3-d-old rats (open circles) and 27- to 29-d old rats (closed circles). Data from each neuron have been normalized to their respective individual $1 \mu \mathrm{M}$ glycine peak response.

msec $(36 \pm 2 \%)($ Fig. $5 B)(n=8$ cells $)$. The time course of the slow component was not significantly different from the on rate in the 2- to 3-d-old neurons (two-tailed $t$-test, $p>0.15$ ). The recovery of the steady-state current after a rapid jump back from the 7-chlorokynurenic acid-containing solution was again best fitted by a two-equivalent binding site model that yielded a mean $\tau$ value of $75 \pm 6 \mathrm{msec}$, which was not significantly different from the value obtained from the younger neurons (two tailed $t$-test, $p>0.76)$. Ifenprodil $(10 \mu \mathrm{M})$ inhibited $68 \pm 3 \%$ of the steadystate current, significantly less than in the 3-d-old neurons (two tailed $t$-test, $p<0.001)$. The decay of the current after rapid application of ifenprodil to neurons of both ages was best fitted with a single exponential (Fig. 5), and after removal of ifenprodil the current recovery was slow $(\tau=\sim 50 \mathrm{sec}$; data not shown), in agreement with our previous observations (Kew et al., 1998) and consistent with ifenprodil binding with high affinity to a single receptor population. A two-phase onset and recovery from block by ifenprodil of steady-state NMDA currents evoked in the pres- ence of high $(\geq 30 \mu \mathrm{M})$ but not low concentrations of ifenprodil has been reported previously (Legendre and Westbrook, 1991). The fast rates of onset and recovery from block at high concentrations of ifenprodil only were attributed to a low-affinity interaction. We have observed a similar two-phase onset and recovery from block of steady-state NMDA currents (100 $\mu \mathrm{M}$ NMDA and $30 \mu \mathrm{M}$ glycine) from 27 - to 29 -d-old neurons by $300 \mu \mathrm{M}$ ifenprodil, which inhibits virtually all of the NMDA-evoked current (Fig. 4), but not $10 \mu \mathrm{M}$ ifenprodil (data not shown), confirming that the low-affinity ifenprodil interaction is readily distinguishable kinetically, and that it is clearly not apparent with $10 \mu \mathrm{M}$ ifenprodil.

\section{Developmental changes in cortical expression of NR2A and NR2B mRNA and protein}

NR2A and NR2B are the predominant NR2 subunits in the cortex both during development and in the adult (Monyer et al., 1992, 1994; Watanabe et al., 1992; Zhong et al., 1995; Wenzel et al., 1997). Therefore, we examined the expression of NR2A and 


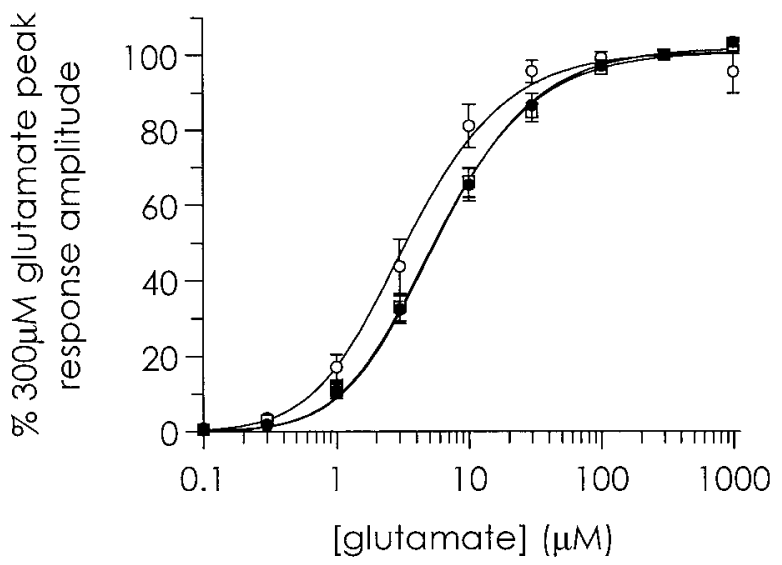

Figure 3. Glutamate concentration-response curves from 2- to 3-d-old cortical neurons (open circles), 14- to 15-d-old cortical neurons (open squares), and 27- to 29-d-old cortical neurons (closed circles). Mean $\pm \mathrm{SE}$ peak currents for each age group have been normalized to their respective $300 \mu \mathrm{M}$ glutamate peak response. Peak inward currents were elicited in response to $2 \mathrm{sec}$ fast applications of increasing concentrations of glutamate in the continuous presence of $30 \mu \mathrm{M}$ glycine and $10 \mu \mathrm{M} \mathrm{NBQX}$. Shown are monophasic curves fitted with the two-equivalent binding site model that yielded $m K_{\mathrm{D}}$ values of $1.4,2.3$, and $2.4 \mu \mathrm{M}$ for 2- to 3-, 14- to $15-$, and 27- to 29-d-old animals, respectively.

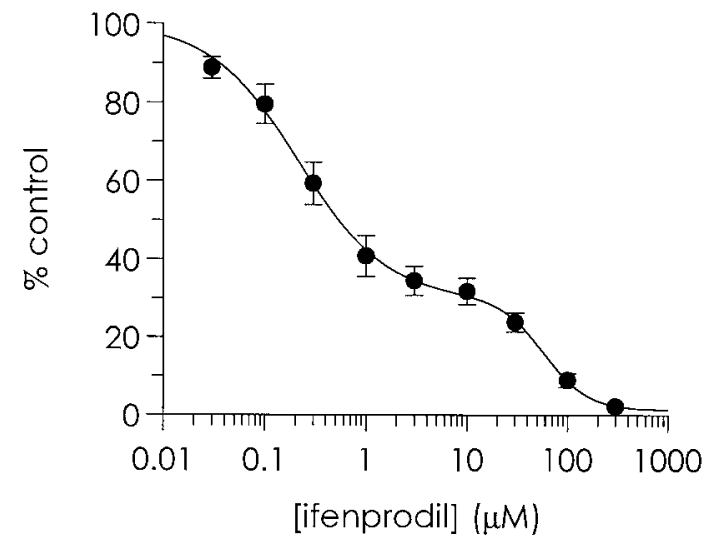

Figure 4. Biphasic ifenprodil inhibition curves from 27- to 29-d-old cortical neurons. The antagonism of $100 \mu \mathrm{M}$ NMDA steady-state currents by increasing concentrations of ifenprodil is expressed as a function of control response (i.e., pre-ifenprodil response amplitude). NMDA (100 $\mu \mathrm{M}$ ) was applied for $5 \mathrm{sec}$ at $25 \mathrm{sec}$ intervals in the continuous presence of $30 \mu \mathrm{M}$ glycine. Increasing concentrations of ifenprodil were applied in both agonist-containing and wash solutions. NMDA applications were made until stable steady-state current levels were attained in the presence of each concentration of ifenprodil. Shown is a curve fitted through the mean data \pm SE obtained from four neurons, using a biphasic model, from which $\mathrm{IC}_{50}$ values and slopes of $0.21 \mu \mathrm{M}$ (slope $=-1$ ) and $58 \mu \mathrm{M}$ (slope $=-2$ ) were obtained for the high- and low-affinity components, respectively. The relative amplitudes of the high- and low-affinity components were 70 and $30 \%$, respectively. Notably, $10 \mu \mathrm{M}$ ifenprodil produced a maximal inhibition of the high-affinity component but left the low-affinity component almost unaffected.

NR2B mRNA and protein in 3-, 14-, and 28-d-old rats. In situ hybridization analysis (Fig. 6) revealed that NR2A mRNA is already expressed at moderate levels in the parietal cortex of 3 -d-old rats $(40 \%)$ and that its expression is maximal $(100 \%)$ at $14 \mathrm{~d}$ and is maintained at $28 \mathrm{~d}$ (from optical density measurements). In contrast, NR2B mRNA is already expressed at its maximum level in 3-d-old animals. This expression level is maintained at $14 \mathrm{~d}$ and then declines to $50 \%$ at $28 \mathrm{~d}$.
Quantitative Western blot analysis of parietal cortex membranes prepared from animals at each time point revealed that the level of NR2B protein was highest in 14-d-old rat cortex (100\%), with 70 and $85 \%$ of the $14 \mathrm{~d}$ level present at 3 and $28 \mathrm{~d}$, respectively (Fig. 7). NR2A protein was highest in 28-d-old rat cortex with $83 \%$ of this maximum level present at $14 \mathrm{~d}$ and undetectable levels in 3-d-old animals (Fig. 7).

\section{DISCUSSION}

In this study we have demonstrated a developmental change in rat cortical neuronal NMDA receptor glycine affinity such that with age a population of NMDA receptors appears that exhibits a markedly lower affinity for glycine. Whereas it has long been accepted that activation of the NMDA receptor requires occupation of both the glutamate and glycine recognition sites (Johnson and Ascher, 1987; Kleckner and Dingledine, 1988), the physiological role of glycine in the regulation of NMDA receptor activity has remained unclear. The glycine concentration in the extracellular and cerebrospinal fluids has been estimated to be in the low micromolar range (Westergren et al., 1994); however, glycine transporters (Zafra et al., 1995) might reduce the glycine concentration to well below $1 \mu \mathrm{M}$ in the local microenvironment of NMDA receptors (Supplisson and Bergman, 1997). The appearance of a population of NMDA receptors with a relatively low affinity for glycine $\left(m K_{\mathrm{D}}=\sim 800 \mathrm{nM}\right.$; maximum response at $\sim 30 \mu \mathrm{M}$ glycine) as revealed in this study, suggests that the extracellular glycine concentration might not be saturating at a proportion of the cortical NMDA receptors in adult rats. Modulation of extracellular glycine concentration, perhaps by activitydependent glycine release, or perhaps by modulation of NMDA receptor affinity for glycine by receptor phosphorylation and dephosphorylation (Wang et al., 1994), might regulate the activity of this receptor subpopulation. Notably, glutamate concentration-response analysis of neurons from all three age groups tested revealed very little developmental change in receptor affinity.

Studies on recombinant NMDA receptors have revealed that in heteromeric receptors composed of NMDAR1 and NR2 subunits, the identity of the NR2 subunit exerts a major influence on receptor glycine affinity (Ikeda et al., 1992; Kutsuwada et al., 1992; Priestley et al., 1995), whereas all NMDAR1 splice variants exhibit similar affinities for glycine (Nakanishi et al., 1992; Durand et al., 1993; Hollmann et al., 1993). Receptors containing NR2D appear to exhibit the highest affinity for both glutamate and glycine (Ikeda et al., 1992), whereas receptors containing NR2A exhibit a markedly lower affinity for glycine relative to the other NR2 subunits (Kutsuwada et al., 1992). In the adult rodent the predominant NR2 subunits in the forebrain are NR2A and NR2B, with NR2C expressed largely in the cerebellum and various select nuclei and NR2D expression confined to the diencephalon and midbrain (Kutsuwada et al., 1992; Monyer et al., 1992, 1994, Ishii et al., 1993; Dunah et al., 1996). Thus, in the adult forebrain the most abundant heteromeric combinations are likely to be NMDAR1-NR2A, NMDAR1-NR2B, and threesubunit-containing NMDAR1-NR2A-NR2B receptors (Sheng et al., 1994; Luo et al., 1997). In the embryonic and early neonatal forebrain, NR2B is expressed at relatively high levels, with expression of NR2A increasing from birth through the second postnatal week, after which time an adult expression pattern is reached (Watanabe et al., 1992; Monyer et al., 1994; Sheng et al., 1994; Zhong et al., 1995; Wenzel et al., 1997). In this study we have confirmed these observations. Despite the expression of 
A

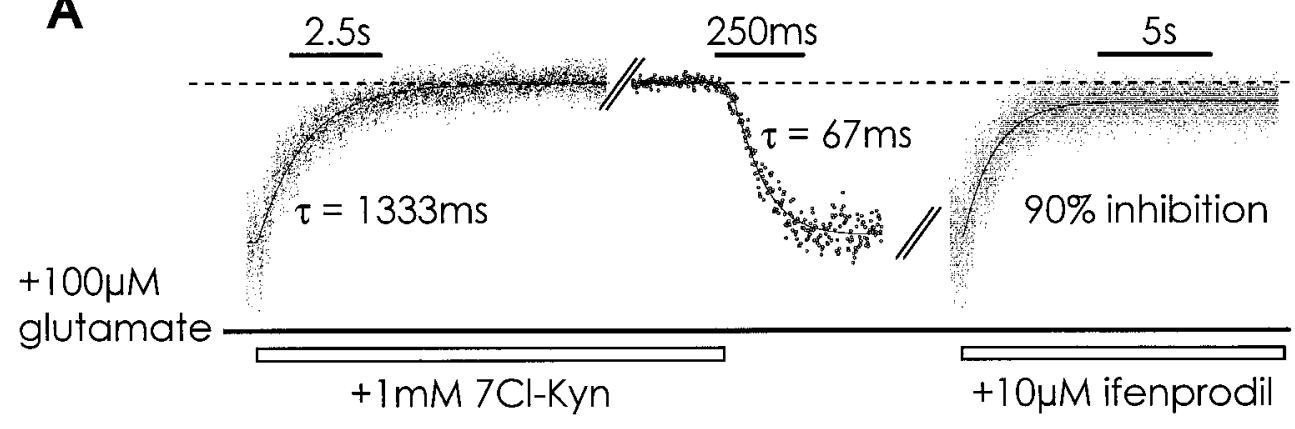

B

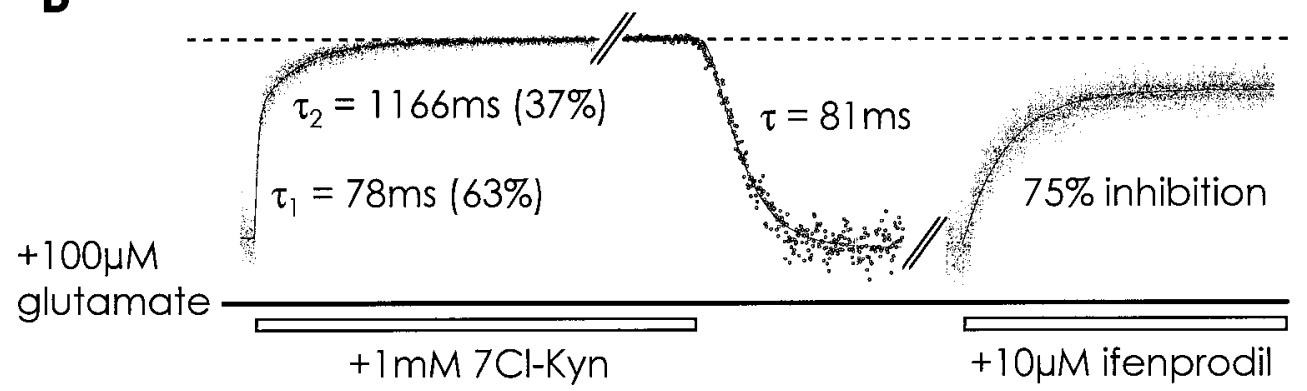

Figure 5. Fast application of 7chlorokynurenic acid during a $100 \mu \mathrm{M}$ glutamate- plus $30 \mu \mathrm{M}$ glycine-evoked steady-state current reveals high- and low-affinity glycine components. Steady-state currents were evoked in 2to 3 -d-old cortical neurons $(A)$ and 27 to 29 -d-old cortical neurons $(B)$ in the continual presence of $10 \mu \mathrm{M}$ NBQX. Steady-state current amplitudes were 70 and $435 \mathrm{pA}$ in $A$ and $B$, respectively. Once a stable steady-state current was attained, a rapid jump was made into an identical solution containing $1 \mathrm{~mm}$ 7-chlorokynurenic acid (7Cl-Kyn) until a stable steady-state current was again achieved, after which a rapid jump was made back into a 7-chlorokynurenic acid-free solution. The jump into and out of 7-chlorokynurenic acid was repeated three times on each neuron. An averaged current inhibition and recovery from a representative neuron in each age group is shown. The decay of the currents after rapid application of 7-chlorokynurenic acid was fitted with single (2- to 3-d-old neurons) and double (27- to 29-d-old neurons) exponential curves, respectively. The current recoveries after removal of 7-chlorokynurenic acid were fitted with the two-equivalent binding site model. After the jumps into 7-chlorokynurenic acid, a rapid jump was made into $100 \mu \mathrm{M}$ glutamate and $10 \mu \mathrm{M}$ ifenprodil. The decay of the current was well fitted by single exponentials $(\tau=720$ and $1000 \mathrm{msec}$ for 2- to 3- and 27- to 29-d-old neurons, respectively). Note the different time scales of the three current traces shown for each age group. Intervening sections of the trace have been omitted for clarity.

PN 3
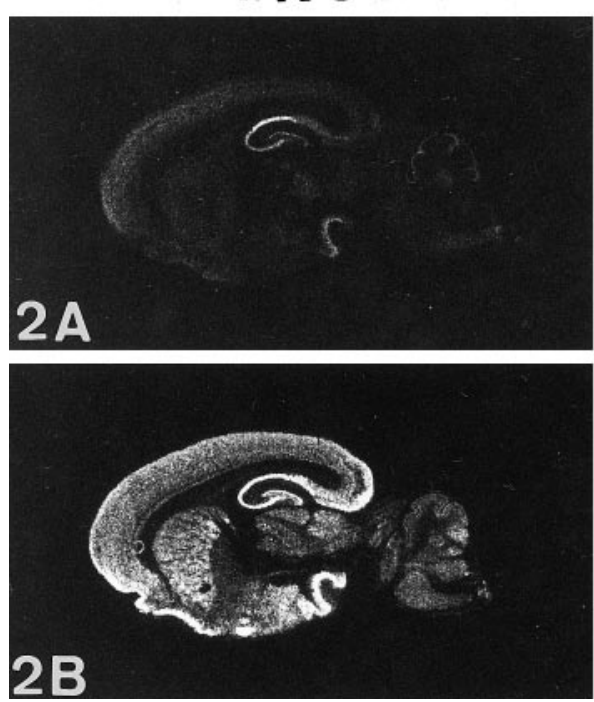

PN 14
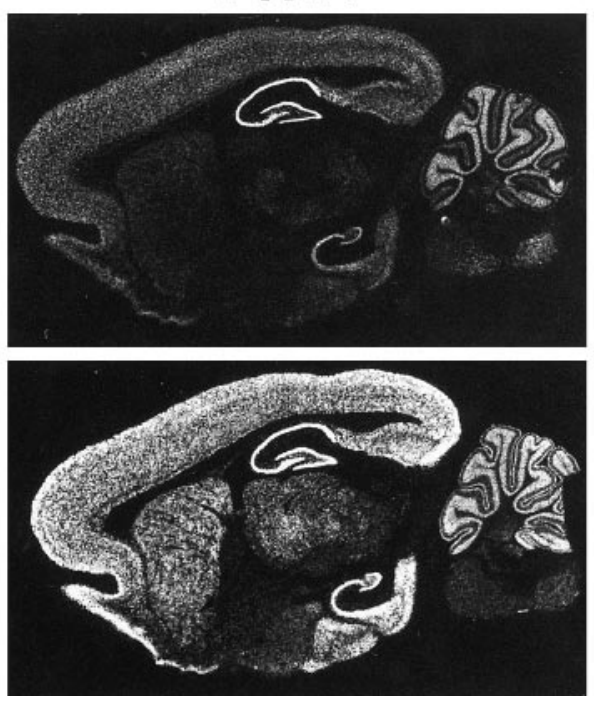

PN 28
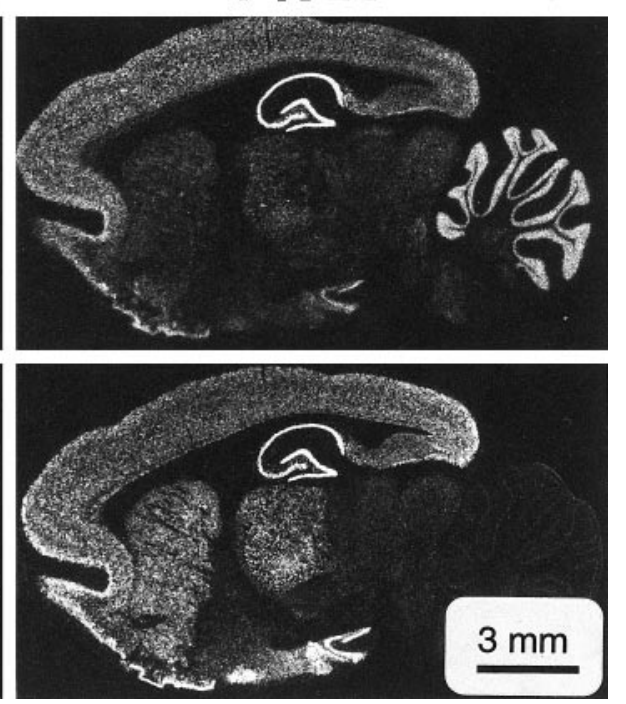

Figure 6. Expression of NR2A and NR2B transcripts in rat brain during ontogeny, revealed by in situ hybridization histochemistry. Note the relatively low level of NR2A hybridization signal (white areas) in postnatal d $3(P N 3)$ parietal cortex and the reduction in the NR2B hybridization signal from PN14 to $\mathrm{PN} 28$.

NR2A mRNA in the cortex of 3-d-old rats, we were unable to detect any NR2A protein by Western blot analysis. The absence of NR2A protein in these neurons is also supported by our pharmacological analysis (discussed below). Interestingly, Wood et al. (1996) have described a 5'-untranslated region of the NR2A mRNA that severely restricts its translation and that may form part of a mechanism controlling translational efficiency. The appearance of NMDA receptors with a low affinity for glycine appears to correlate well with the increased expression of NR2A mRNA and protein at 14 and particularly $28 \mathrm{~d}$, at which time it is accompanied by a decrease in NR2B mRNA and protein. Thus, of the time points examined, the ratio of $\mathrm{NR} 2 \mathrm{~A} / \mathrm{NR} 2 \mathrm{~B}$ protein is at its highest at $28 \mathrm{~d}$.

Ifenprodil is a subtype-selective NMDA antagonist that exhibits $\sim 400$-fold higher affinity for NMDAR1-1a-NR2B than for NMDAR1-1a-NR2A heteromeric receptors (Williams, 1993). In 


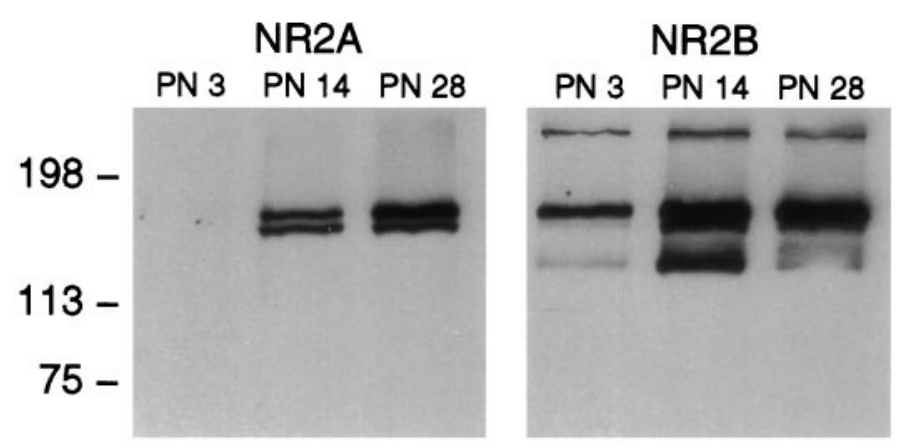

Figure 7. Expression of NR2A and NR2B protein in rat parietal cortex during ontogeny, revealed by Western blot analysis. Note that the absolute optical densities for NR2A and NR2B are not comparable because of the different affinities of the antibodies.

this study we have assayed the inhibition of steady-state currents by $10 \mu \mathrm{M}$ ifenprodil, a concentration that maximally inhibits currents elicited in Xenopus oocytes expressing NR2B but leaves currents in oocytes expressing NR2A almost unaffected (Williams, 1993). We have demonstrated, both with inhibition curves and kinetically, that $10 \mu \mathrm{M}$ ifenprodil exhibits only a high-affinity interaction with NMDA receptors expressed in 27- to 29-d-old neurons, and that it produces a maximal inhibition of the highaffinity ifenprodil component of the current. Furthermore, the proportion of NMDA steady-state current inhibited by ifenprodil $(10 \mu \mathrm{M})$ decreased with age, in agreement with previous studies (Williams et al., 1993), again apparently correlating well with the increased expression of the ifenprodil-insensitive NR2A subunit at 14 and $28 \mathrm{~d}$.

Ifenprodil $(10 \mu \mathrm{M})$ inhibited currents elicited in neurons from 2- to 3-d-old animals almost completely, as would be predicted from the presence of NR2B and absence of NR2A protein. From studies with recombinant receptors it can be predicted that native NMDA receptors containing only NR2B would exhibit a relatively high affinity for glycine (Kutsuwada et al., 1992; Priestley et al., 1995). This prediction is supported by our observations that glycine concentration-response curves on cortical neurons from 2- to 3-d-old animals were monophasic and of high affinity, and that the decay of $100 \mu \mathrm{M}$ glutamate/30 $\mu \mathrm{M}$ glycine-evoked steadystate currents after rapid application of 7-chlorokynurenic acid were well fitted by a single exponential with slow kinetics. Thus, it appears likely that the large majority of NMDA receptors in cortical neurons from these very young animals contain NR2B as the sole NR2 subunit. We have not assessed the expression of NR2D, which has been shown to be expressed at relatively low levels in the rat cortex (Dunah et al., 1996; Wenzel et al., 1996), in neurochemically identified interneurons (Standaert et al., 1996). Recombinant receptors containing NR2D exhibit the highest affinity for glycine (Ikeda et al., 1992) but also display a significantly higher affinity for glutamate (Ikeda et al., 1992) and NMDA (Buller and Monaghan, 1997) as well as an extremely slow current deactivation after removal of glutamate (Monyer et al., 1994). Furthermore, they are insensitive to blockade by $10 \mu \mathrm{M}$ ifenprodil (Williams, 1995). We have not observed a similar pharmacological profile in this study, suggesting that NR2D was not expressed or was expressed at very low levels in the neurons we recorded from.

Cortical neurons from 27- to 29-d-old animals are likely to contain both NR2A and NR2B protein and, accordingly, to contain NMDA receptors with high and low glycine affinity and high and low sensitivity to ifenprodil. The fast and slow components of the decay of the glutamate steady-state currents after rapid application of 7-chlorokynurenic acid represent the lowand high-affinity glycine components, respectively (Benveniste et al., 1990; Priestley and Kemp, 1993). Whereas $10 \mu \mathrm{M}$ ifenprodil inhibited almost all of the $100 \mu \mathrm{M}$ glutamate-evoked steady-state current in 3-d-old neurons, in which only the high-affinity glycine component is evident, it inhibited $68 \pm 3 \%$ in 28 -d-old neurons, significantly more than the proportion of the high-affinity (slow) glycine component ( $36 \pm 2 \%$; two tailed $t$-test, $p<0.0001)$. Thus, in 28-d-old neurons ifenprodil inhibits both the high-affinity glycine component of the current and a considerable portion (by subtraction of the above values, $\sim 50 \%$ ) of the low-affinity glycine component.

NMDA receptor activation requires occupation of two independent glycine sites (Benveniste and Mayer, 1991; Clements and Westbrook, 1991), and thus, the current relaxation after removal of glycine (or addition of 7-chlorokynurenic acid) reflects the rate of glycine dissociation from the lower-affinity site (i.e., the site with the fastest rate of dissociation). Accordingly, if an NMDA receptor contained both $\mathrm{NR} 2 \mathrm{~A}$ and $\mathrm{NR} 2 \mathrm{~B}$, which conferred distinct affinities on each of the two glycine sites, it would be the lower-affinity site that determined the functional glycine affinity of the receptor. Furthermore, if the inhibitory effect of ifenprodil was mediated by occupation of only a single high-affinity binding site, as suggested by the slope of monophasic, high-affinity ifenprodil inhibition curves (Kew et al., 1996) and the slope of the high-affinity component of the biphasic inhibition curve from 27to 29-d-old neurons, the presence of a single NR2B subunit, which contains amino acids critical for high-affinity ifenprodil binding (Gallagher et al., 1996), would be sufficient to confer high-affinity ifenprodil sensitivity. Thus, ifenprodil would bind with high affinity to NMDA receptors exhibiting low glycine affinity that contain both NR2A and NR2B subunits, in accord with our findings.

Thus, our results suggest that individual cortical neurones of 27- to 29-d-old rats contain at least three populations of NMDA receptors: (1) receptors exhibiting high affinity for glycine, slow glycine dissociation kinetics, and high-affinity block by ifenprodil, which contain NR2B as the sole NR2 subunit, (2) receptors exhibiting low affinity for glycine, fast glycine dissociation kinetics, and insensitivity to ifenprodil, which contain NR2A as the sole NR2 subunit, and (3) receptors exhibiting low affinity for glycine, fast glycine dissociation kinetics, and high-affinity block by ifenprodil, which are likely to contain both NR2A and NR2B.

\section{REFERENCES}

Benveniste M, Mayer ML (1991) Kinetic analysis of antagonist action at $N$-methyl-D-aspartic acid receptors. Biophys J 59:560-573.

Benveniste M, Mienville JM, Sernagor E, Mayer ML (1990) Concentration-jump experiments with NMDA antagonists in mouse cultured hippocampal neurons. J Neurophysiol 63:1373-1384.

Borowsky B, Mezey E, Hoffman BJ (1993) Two glycine transporter variants with distinct localization in the CNS and peripheral tissues are encoded by a common gene. Neuron 10:851-863.

Buller AL, Monaghan DT (1997) Pharmacological heterogeneity of NMDA receptors: characterization of NR1a/NR2D heteromers expressed in Xenopus oocytes. Eur J Pharmacol 320:87-94.

Clements JD, Westbrook GL (1991) Activation kinetics reveal the number of glutamate and glycine binding sites on the $N$-Methyl-D-aspartate receptor. Neuron 7:605-613.

Danysz W, Wroblewski JT, Brooker G, Costa E (1989) Modulation of glutamate receptors by phencyclidine and glycine in the rat cerebellum: cGMP increase in vivo. Brain Res 479:270-276.

Dunah AW, Yasuda RP, Wang YH, Luo JH, Davila-Garcia MI, 
Gbadegesin M, Vicini S, Wolfe BB (1996) Regional and ontogenic expression of the NMDA receptor subunit NR2D protein in rat brain using a subunit-specific antibody. J Neurochem 67:2335-2345.

Durand GM, Bennett MV, Zukin RS (1993) Splice variants of the $N$-methyl-D-aspartate receptor NR1 identify domains involved in regulation by polyamines and protein kinase C. Proc Natl Acad Sci USA 90:6731-6735.

Fletcher EJ, Lodge D (1988) Glycine reverses antagonism of $N$-methylD-aspartate (NMDA) by 1- hydroxy-3-aminopyrrolidone-2 (HA-966) but not by D-2-amino-5-phosphonovalerate (D-AP5) on rat cortical slices. Eur J Pharmacol 151:161-162.

Gallagher MJ, Huang H, Pritchett DB, Lynch DR (1996) Interactions between ifenprodil and the NR2B subunit of the $N$-methyl-D-aspartate receptor. J Biol Chem 271:9603-9611.

Hollmann M, Boulter J, Maron C, Beasley L, Sullivan J, Pecht G, Heinemann S (1993) Zinc potentiates agonist-induced currents at certain splice variants of the NMDA receptor. Neuron 10:943-954.

Ikeda K, Nagasawa M, Mori H, Araki K, Sakimura K, Watanabe M, Inoue Y, Mishina M (1992) Cloning and expression of the $\epsilon 4$ subunit of the NMDA receptor channel. FEBS Lett 313:34-38.

Ishii T, Moriyoshi K, Sugihara H, Sakurada K, Kadotani H, Yokoi M, Akazawa C, Shigemoto R, Mizuno N, Masu M, Nakanishi S (1993) Molecular characterization of the family of the $N$-methyl-D-aspartate receptor subunits. J Biol Chem 268:2836-2843.

Johnson JW, Ascher P (1987) Glycine potentiates the NMDA response in cultured mouse brain neurons. Nature 325:529-531.

Kemp JA, Leeson PD (1993) The glycine site of the NMDA receptorfive years on. Trends Pharmacol Sci 14:20-25.

Kemp JA, Foster AC, Leeson PD, Priestley T, Tridgett R, Iversen LL, Woodruff GN (1988) 7-Chlorokynurenic acid is a selective antagonist at the glycine modulatory site of the $N$-methyl-D-aspartate receptor complex. Proc Natl Acad Sci USA 85:6547-6550.

Kew JNC, Trube G, Kemp JA (1996) A novel mechanism of activitydependent NMDA receptor antagonism describes the effect of ifenprodil in rat cultured cortical neurones. J Physiol (Lond) 497:761-772.

Kew JNC, Trube G, Kemp JA (1998) State-dependent NMDA receptor antagonism by Ro 8-4304, a novel NR2B selective, noncompetitive, voltage-independent antagonist. Br J Pharmacol, in press.

Kleckner NW, Dingledine R (1988) Requirement for glycine in activation of NMDA-receptors expressed in Xenopus oocytes. Science 241:835-837.

Kutsuwada T, Kashiwabuchi N, Mori H, Sakimura K, Kushiya E, Araki K, Meguro H, Masaki H, Kumanishi T, Arakawa M, Mishina M (1992) Molecular diversity of the NMDA receptor channel. Nature 358:36-41.

Laube B, Hirai H, Sturgess M, Betz H, Kuhse J (1997) Molecular determinants of agonist discrimination by NMDA receptor subunits: analysis of the glutamate binding site on the NR2B subunit. Neuron 18:493-503.

Legendre P, Westbrook GL (1991) Ifenprodil blocks $N$-methyl-Daspartate receptors by a two-component mechanism. Mol Pharmacol 40:289-298.

Llano L, Marty A, Johnson JW, Ascher P, Gahwiler BH (1988) Patchclamp recording of amino acid-activated responses in "organotypic" slice cultures. Proc Natl Acad Sci USA 85:3221-3225.

Luo J, Wang Y, Yasuda RP, Dunah AW, Wolfe BB (1997) The majority of $N$-Methyl-D-aspartate receptor complexes in adult rat cerebral cortex contain at least three different subunits (NR1/NR2A/NR2B). Mol Pharmacol 51:79-86.

McBain CJ, Mayer ML (1994) N-Methyl-D-aspartic acid receptor structure and function. Physiol Rev 74:723-760.

Monyer H, Sprengel R, Schoepfer R, Herb A, Higuchi M, Lomeli H, Burnashev N, Sakmann B, Seeburg PH (1992) Heteromeric NMDA receptors: molecular and functional distinction of subtypes. Science 256:1217-1221.

Monyer H, Burnashev N, Laurie DJ, Sakmann B, Seeburg PH (1994) Developmental and regional expression in the rat brain and functional properties of four NMDA receptors. Neuron 12:529-540.

Nakanishi N, Axel R, Shneider NA (1992) Alternative splicing generates functionally distinct $N$-methyl-D-aspartate receptors. Proc Natl Acad Sci USA 89:8552-8556.

Obrenovitch TP, Hardy AM, Urenjak J (1997) High extracellular glycine does not potentiate $N$-methyl-D-aspatate-evoked depolarization in vivo. Brain Res 746:190-194.
Priestley T, Kemp JA (1993) Agonist response kinetics of $N$-methyl-Daspartate receptors in neurons cultured from rat cerebral cortex and cerebellum: evidence for receptor heterogeneity. Mol Pharmacol 44:1252-1257.

Priestley T, Ochu E, Kemp JA (1994) Subtypes of NMDA receptors in neurones cultured from rat brain. NeuroReport 5:1763-1765.

Priestley T, Laughton P, Myers J, Le Bourdelles B, Kerby J, Whiting PJ (1995) Pharmacological properties of recombinant human $N$-methyl-Daspartate receptors comprising NR1a/NR2A and NR1a/NR2B subunit assemblies expressed in permanently transfected mouse fibroblast cells. Mol Pharmacol 48:841-848.

Sheng M, Cummings J, Roldan LA, Jan YN, Jan LY (1994) Changing subunit composition of heteromeric NMDA receptors during development of rat cortex. Nature 368:144-147.

Singh L, Oles RJ, Tricklebank MD (1990) Modulation of seizure susceptibility in the mouse by the strychnine-insensitive glycine recognition site of the NMDA receptor/ion channel complex. Br J Pharmacol 99:285-288.

Smith KE, Borden LA, Hartig PR, Branchek T, Weinshank RL (1992) Cloning and expression of a glycine transporter reveal colocalization with NMDA receptors. Neuron 8:927-935.

Standaert DG, Landwehrmeyer GB, Kerner JA, Penney JB, Young AB (1996) Expression of NMDAR2D glutamate receptor subunit mRNA in neurochemically identified interneurons in the rat neostriatum, neocortex and hippocampus. Mol Brain Res 42:89-102.

Supplisson S, Bergman C (1997) Control of NMDA receptor activation by a glycine transporter co-expressed in Xenopus oocytes. J Neurosci 17:4580-4590.

Thomson AM, Walker VE, Flynn DM (1989) Glycine enhances NMDA-receptor mediated synaptic potentials in neocortical slices. Nature 338:422-424.

Wang LY, Orser BA, Brautigan DL, MacDonald JF (1994) Regulation of NMDA receptors in cultured hippocampal neurons by protein phosphatases 1 and 2A. Nature 369:230-232.

Watanabe M, Inoue Y, Sakimura K, Mishina M (1992) Developmental changes in distribution of NMDA receptor channel subunit mRNAs. NeuroReport 3:1138-1140.

Wenzel A, Villa M, Mohler H, Benke D (1996) Developmental and regional expression of NMDA receptor subtypes containing the NR2D subunit in rat brain. J Neurochem 66:1240-1248.

Wenzel A, Fritschy JM, Mohler H, Benke D (1997) NMDA receptor heterogeneity during postnatal development of the rat brain: differential expression of the NR2A, NR2B, and NR2C subunit proteins. J Neurochem 68:469-478.

Westergren I, Nystrom B, Hamberger A, Nordborg C, Johansson B (1994) Concentrations of amino acids in extracellular fluid after opening of the blood-brain barrier by intracarotid infusion of protamine sulfate. J Neurochem 62:159-165.

Wilcox KS, Fitzsimonds RM, Johnson B, Dichter MA (1996) Glycine regulation of synaptic NMDA receptors in hippocampal neurons. J Neurophysiol 76:3415-3424.

Williams K (1993) Ifenprodil discriminates subtypes of the $N$-methyl-Daspartate receptor: selectivity and mechanisms at recombinant heteromeric receptors. Mol Pharmacol 44:851-859.

Williams K (1995) Pharmacological properties of recombinant $N$-methylD-aspartate (NMDA) receptors containing the epsilon 4 (NR2D) subunit. Neurosci Lett 184:181-184.

Williams K, Russell SL, Shen YM, Molinoff PB (1993) Developmental switch in the expression of NMDA receptors occurs in vivo and in vitro. Neuron 10:267-278.

Wood MW, Vandongen HMA, Vandongen AMJ (1996) The 5'untranslated region of the $N$-methyl-D-aspartate receptor NR2A subunit controls efficiency of translation. J Biol Chem 271:8115-8120.

Wood PL, Emmett MR, Rao TS, Mick S, Cler J, Iyengar S (1989) In vivo modulation of the $N$-methyl-D-aspartate receptor complex by D-serine: potentiation of ongoing neuronal activity as evidenced by increased cerebellar cyclic GMP. J Neurochem 53:979-981.

Zafra F, Aragon C, Olivares L, Danbolt NC, Gimenez C, Storm-Mathisen J (1995) Glycine transporters are differentially expressed among CNS cells. J Neurosci 15:3952-3969.

Zhong J, Carrozza DP, Williams K, Pritchett DB, Molinoff PB (1995) Expression of mRNAs encoding subunits of the NMDA receptor in developing rat brain. J Neurochem 64:531-539. 